\title{
An empirical study on the influencing factors of environmental information disclosure of Chinese mining listed companies
}

\author{
Li Zhijuan, Zhou Chaoyang
}

School of Management, Wuhan University of Technology, Wuhan, P.R.China, 430070

*email:2507889472@qq.com

\begin{abstract}
This paper conducts the research based on the data of environmental information disclosure of 75 Chinese mining listed companies in 2015. The disclosure of environmental information was extracted from the published annual report information, independent social responsibility report. The size, profitability, financial leverage, ownership concentration, the proportion of state-owned holding of listed companies were selected, whether these factors will affect the environmental disclosure of listed companies is to be found out through this empirical analysis. The results show that there is a significant positive correlation between the size, profitability, financial leverage, ownership concentration and the level of environmental information disclosure of listed companies, among these factors the impact of the company's profitability, financial leverage is relatively large.
\end{abstract}

Key words: Environmental information disclosure, Influencing factor, Mining industry, Chinese listed companies, Empirical study.

\section{Introduction}

With the rapid development of economy, the increasingly prominent environmental problems become the focus of people's attention, the environmental information released by listed companies has become an important basis for investors to make investment decisions. The disclosure of environmental information is connected with the financial report of the enterprise. The disclosure of environmental information aims to promote the communication with stakeholders. In the early time, as an integral part of corporate social responsibility report, environmental information disclosure reflected in the company's annual report. Now people pay more and more attention to environmental protection, therefore the public's concern about environmental information disclosure is higher, and the pressure of the company is also bigger. So many listed companies have increased environmental information disclosure in the annual report, some listed companies reveal separate social responsibility reports to the public. Under this background, we carry out this research.

\section{Literature review and Hypotheses}

The larger the company, the bigger the social influence, the concern of the public, media, government and other institutions is also higher. In order to maintain its image and social reputation, more environmental information will be revealed. Tagesson 
(2009) found that the size of companies had a positive correlation with the level of environmental information disclosure. Thus:

H1: The larger the size of enterprises, the higher the level of environmental information disclosure.

In the process of production, when the companies get strong profitability, good business performance, the environmental protection consciousness is stronger, the companies have more resources to put into the environmental protection, and are more responsible for society. Frost (2008) studied the disclosure of environmental information in the annual report of the Australian mining enterprises, the results show that the profitability is related with the corporate environmental information disclosure. Based on this, the following hypothesis was proposed:

$\mathrm{H} 2$ : The stronger the profitability of enterprises, the higher the level of environmental information disclosure.

In order to ensure financing of the companies, to keep a good relationship with stakeholders, the companies try to reveal more environmental information, which also helps to maintain the stability and reduce the financial risk of the companies. Zheng Chunmei (2013) found that there was a positive correlation between financial leverage and environmental information disclosure. Due to the increase in debt level, enterprises try to relieve the anxiety of shareholders and creditors by revealing more environmental information. Based on this, the hypothesis was put forward:

H3: The higher level of the corporate debt, the higher the level of environmental information disclosure.

Haskins' (2000) study showed that Europe's equity was more dispersed, the requirement of shareholders on environmental information disclosure were also higher, so the environmental information disclosure level were higher; In Asia the information disclosure level was lower because the relative concentration of ownership, disclosure requirements on the report of the shareholders were not as strictly as Europe. Based on this, the research puts forward the hypothesis 4:

H4: The more dispersed the ownership, the higher the requirement of environmental information disclosure.

\section{Research Design}

\subsection{Sample selection and data sources}

This research selects 75 Chinese mining listed companies as samples. The Sample data of environmental information disclosure are obtained from the annual reports and the independent social responsibility reports (including the sustainable development reports). The size and net assets income rate of the companies are mainly obtained from Tai an database, hexun.com. After removing the companies which are not complete in the financial statements, ST companies, the companies which have been delisted, finally 75 companies are selected. The reason why we choose the mining industry mainly attributes to the great destruction to the environment during the whole process of exploitation, so it should take larger responsibility to protect the environment, and thus the mining industry becomes the representative of this research. 


\subsection{Variable research}

When the environmental information disclosure index (EDI) is measured, we use the content analysis method to evaluate the information quality of listed companies. According to the 2008 implementation of the environmental information disclosure approach (Trial), the samples are scored. If the company's annual reports with free environment information disclosure get 0 point, descriptive information disclosure are graded with 1 point, 2 points of information disclosure with monetary valuation, independent social responsibility report is to assign 1 point, finally the points are added, which reflect the level of environmental disclosure index (EDI), which are 4 points totally.

Figure 1: variable definition table

\begin{tabular}{|c|c|c|c|}
\hline $\begin{array}{l}\text { Variable } \\
\text { type }\end{array}$ & $\begin{array}{l}\text { Variable } \\
\text { code }\end{array}$ & Variable name & Variable definition \\
\hline $\begin{array}{l}\text { Explained } \\
\text { variable }\end{array}$ & EDI & $\begin{array}{c}\text { Environmental } \\
\text { information disclosure } \\
\text { index }\end{array}$ & $\begin{array}{c}\text { The level of } \\
\text { environmental information } \\
\text { disclosure }\end{array}$ \\
\hline \multirow{5}{*}{$\begin{array}{l}\text { Explanatory } \\
\text { variable }\end{array}$} & SIZE & Company size & $\begin{array}{l}\text { Natural logarithm of total } \\
\text { assets of the company }\end{array}$ \\
\hline & ROE & Return on net assets & $\begin{array}{c}\text { On behalf of the } \\
\text { profitability of listed } \\
\text { companies }\end{array}$ \\
\hline & LEV & Financial leverage & $\begin{array}{c}\text { On behalf of the } \\
\text { company's financial leverage }\end{array}$ \\
\hline & $\mathrm{H}$ & $\begin{array}{r}\text { Ownership } \\
\text { concentration }\end{array}$ & $\begin{array}{l}\text { the top five shareholders' } \\
\text { sharing ratio }\end{array}$ \\
\hline & GA & National share ratio & $\begin{array}{l}\text { The proportion of the } \\
\text { shares held by the } \\
\text { shareholders on behalf of the } \\
\text { state investment institutions }\end{array}$ \\
\hline
\end{tabular}

\subsection{Model design}

In the research, descriptive statistics, correlation analysis and multiple regression analysis are used to study the main factors affecting the level of information disclosure of listed companies in China. According to the hypothesis, the following research model is established:

$$
\mathrm{EDI}=\beta_{0}+\beta_{1} \mathrm{SIZE}+\beta_{2} \mathrm{ROE}+\beta_{3} \mathrm{LEV}+\beta_{4} \mathrm{H}+\beta_{5} \mathrm{GA}+\varepsilon
$$

$\beta_{0}$ is constant, $\beta_{1} \sim \beta_{5}$ is the regression coefficient, it means how the explained variables change with the change of explanatory, $\varepsilon$ is as a random disturbance term.

\section{Empirical Analyses}

\subsection{Descriptive statistic}

Figure 2 describes the descriptive statistical results of the full sample environmental information disclosure index. The whole mean of the sample is 2.16 (full score is 4). 
Figure 2: descriptive results of environmental information disclosure

\begin{tabular}{|l|c|c|c|c|r|}
\hline \multicolumn{1}{|c|}{ Type } & N & Minimum & Maximum & Mean & $\begin{array}{r}\text { Standard } \\
\text { deviation }\end{array}$ \\
\hline Descriptive disclosure & 75 & 0 & 1 & 0.83 & 0.724 \\
Monetary disclosure & 75 & 0 & 2 & 0.80 & 0.885 \\
Independent social & 75 & 0 & 1 & 0.53 & 0.502 \\
responsibility report & 75 & 0 & 4 & 2.16 & 1.386 \\
Environmental information & & & & & \\
disclosure index & & & & \\
Effective N (List status) & 75 & & & & \\
\hline
\end{tabular}

From the above table, we can see that the maximum value of descriptive disclosure is 1 and the mean value is about 0.83 , which shows that the majority of companies have made simple disclosure of environmental information in the selected samples; The maximum value of the currency disclosure is 2 , but the mean value is 0.80 , which indicates that only a small number of companies in the selected samples have made monetary disclosure; The maximum value of the independent social responsibility report is 1 , the mean value is 0.53 , which shows that in the selected samples, there are over half of the companies have disclosed independent social responsibility report.

\subsection{Correlation analyses}

Figure 3: correlation test

\begin{tabular}{|c|c|c|c|c|c|c|c|}
\hline & & EDI & SIZE & $\mathrm{ROE}$ & LEV & $\mathrm{H}$ & GA \\
\hline \multirow[t]{3}{*}{ EDI } & Pearson relevance & 1 & $.519 * *$ & $.278^{*}$ & $.453 * *$ & $.460 * *$ & .145 \\
\hline & $\begin{array}{l}\text { Significant } \\
\text { (bilateral) }\end{array}$ & & .000 & .016 & .000 & .000 & .213 \\
\hline & $\mathrm{N}$ & 75 & 75 & 75 & 75 & 75 & 75 \\
\hline \multirow[t]{3}{*}{ SIZE } & Pearson relevance & $.519 * *$ & 1 & .108 & $.388 * *$ & $.628 * *$ & .116 \\
\hline & $\begin{array}{l}\text { Significant } \\
\text { (bilateral) }\end{array}$ & .000 & & .355 & .001 & .000 & .322 \\
\hline & $\mathrm{N}$ & 75 & 75 & 75 & 75 & 75 & 75 \\
\hline \multirow[t]{3}{*}{ ROE } & Pearson relevance & $.278^{*}$ & .108 & 1 & -.193 & -.014 & .121 \\
\hline & $\begin{array}{l}\text { Significant } \\
\text { (bilateral) }\end{array}$ & .016 & .355 & & .097 & .907 & .301 \\
\hline & $\mathrm{N}$ & 75 & 75 & 75 & 75 & 75 & 75 \\
\hline \multirow[t]{3}{*}{ LEV } & Pearson relevance & $.453 * *$ & $.388 * *$ & -.193 & 1 & $.280^{*}$ & -.041 \\
\hline & $\begin{array}{l}\text { Significant } \\
\text { (bilateral) }\end{array}$ & .000 & .001 & .097 & & .015 & .729 \\
\hline & $\mathrm{N}$ & 75 & 75 & 75 & 75 & 75 & 75 \\
\hline
\end{tabular}


Figure 3, cont

\begin{tabular}{|c|c|c|c|c|c|c|c|}
\hline \multirow[t]{2}{*}{$\mathrm{H}$} & $\begin{array}{l}\text { Pearson relevance } \\
\text { Significant } \\
\text { (bilateral) }\end{array}$ & $\begin{array}{l}.460 * * \\
.000\end{array}$ & $\begin{array}{l}.628 * * \\
.000\end{array}$ & $\begin{array}{l}-.014 \\
.907\end{array}$ & $\begin{array}{l}.280 * \\
.015\end{array}$ & 1 & $\begin{array}{l}-.267 * \\
.021\end{array}$ \\
\hline & $\mathrm{N}$ & 75 & 75 & 75 & 75 & 75 & 75 \\
\hline \multirow[t]{3}{*}{ GA } & Pearson relevance & .145 & .116 & .121 & -.041 & $-.267 *$ & 1 \\
\hline & $\begin{array}{l}\text { Significant } \\
\text { (bilateral) }\end{array}$ & .213 & .322 & .301 & .729 & .021 & \\
\hline & $\mathrm{N}$ & 75 & 75 & 75 & 75 & 75 & 75 \\
\hline
\end{tabular}

**. Significant correlation at 0.01 level (bilateral)

*. Significant correlation at 0.05 level (bilateral)

According to figure 3, the results of correlation analysis explain there is a significant positive correlation (in the 0.01 or 0.05 level) between variable environmental information disclosure index (EDI) and the size of the company (SIZE), profitability (ROE), financial leverage (LEV), ownership concentration $(\mathrm{H})$, in addition to the proportion of state shares (GA).

\subsection{Regression analyses}

Figure 4: regression analysis and significance test

\begin{tabular}{|c|c|c|c|c|c|}
\hline \multirow{2}{*}{ Model } & \multicolumn{2}{|c|}{$\begin{array}{c}\text { Non standardized } \\
\text { coefficient }\end{array}$} & \multicolumn{1}{c|}{$\begin{array}{c}\text { Standardized } \\
\text { coefficient }\end{array}$} & \multirow{2}{*}{$\mathrm{t}$} & Sig. \\
\cline { 2 - 4 } & $\mathrm{B}$ & $\begin{array}{c}\text { Standard } \\
\text { error }\end{array}$ & Beta & & \\
\hline (Constant) & -2.232 & 1.997 & & -1.118 & .267 \\
SIZE & .142 & .092 & .184 & 1.541 & .028 \\
ROE & 2.487 & .675 & .334 & 3.682 & .000 \\
LEV & 2.303 & .594 & .378 & 3.881 & .000 \\
H & 1.909 & .882 & .243 & 2.165 & .034 \\
\hline
\end{tabular}

a. Dependent variable: environmental information disclosure index

We can see that different independent variables affect the level of environmental information disclosure from the beta value of each variable. The standard coefficient beta values of return on net assets and asset liability ratio are $0.334,0.378$, It shows that the profitability(ROE), financial leverage (LEV) of listed companies in China's mining industries have relatively significant impact on the level of environmental information disclosure.

\section{Conclusions}

The above research results support hypothesis 1, hypothesis 2, hypothesis 3, and hypothesis 4. So this empirical analysis comes to the conclusions as follows: the larger companies tend to disclose more environmental information. Companies with 
strong profitability have a significant positive impact on environmental information disclosure. The companies have more funds to fulfill the environmental responsibility so that they have the initiatives to disclosure full environmental information. There is positive correlation between the debt and the environmental information disclosure of the listed companies. The listed companies are willing to disclosure more environmental information in order to establish good image and long-term development of the companies.

\section{References}

[1] Lisa A Eiler, Jose Miranda-Lopez, Isho Tama-Sweet.The Impact of Accounting Disclosures and the Regulatory Environment on the Information Content of Earnings Announcements [J].The International Journal of Accounting, 2015.

[2] Li Shiyou, Nwaeze Emeka T.The Association between Extensions in XBRL Disclosuresand Financial Information Environment[J].Journal of Information Systems, 2015.

[3] Hoover Scott, Fafatas Stephan. Political environment and voluntary disclosure in the US: Evidence from the Carbon Disclosure environment[J]. Journal of Public Affairs, 2016.

[4] Tagesson T, Collin S-O, Blank V, Broberg P. What explains the extent and content of social and environmental disclosures on corporate websites: A study of social and environmental reporting in Swedish listed corporations[J].Corporate Social Responsibility and Environmental Management,2009.

[5] Zheng Chunmei, Xiang Chun. An Empirical Study on Influencing Factors of Environmental Information Disclosure in 175 Chinese Listed Companies [J]. Science and technology progress and countermeasure, 2013(In Chinese).

[6] Haskins M.E, Ferris K.R, Selling TI. International financial reporting and analysis: a contextual emphasis. IrwinMeGraw-Hill, Boston, 2000.

[7] Geoffrey R Frost. The Introduction of Mandatory Environmental Reporting Guidelines: Australian Evidence [J]. Abacus,2008 (2).

[8] Gurdip Singh Batra. Environment Management and Environmental Disclosures: A Comparison of Corporate Practices Across Malaysia, Singapore and India [J].South Asian Journal of Management, 2013.

[9] Ariff Akmalia M, Cahan Steven F, Emanuel David M. Institutional Environment, Ownership, and Disclosure of Intangibles: Evidence from East Asia.Journal of International Accounting Research[J], 2014.

[10]Chen Zhe, Gallagher David R, Lee Adrian D. Testing the effect of portfolio holdings disclosure in an environment absent of mandatory disclosure[J]. Accounting \& Finance, 2015. 